\title{
Aberrations in Renal Function Parameters Following Oral Administration of Phyllanthus amarus in Cadmium-Induced Kidney Damage in Adult Wistar Rats
}

\author{
Ogunnaike Philip Olubunmi ${ }^{1}$, Olatunji Sunday Yinka ${ }^{1,2,}$, Owolabi Joshua Oladele ${ }^{1}$, \\ Olanrewaju Afees John' ${ }^{1}$, Baderinwa Deborah Boluwatife ${ }^{1}$, Fabiyi Sunday Oluseyi ${ }^{1}$ \\ ${ }^{1}$ Department of Anatomy, Ben Carson Senior School of Medicine, Babcock University, Ilisan Remo, Nigeria \\ ${ }^{2}$ Department of Anatomy and Cell Biology, Obafemi Awolowo University, Ile-Ife, Nigeria
}

Email address:

olatunjis@babcock.edu.ng (O. S. Yinka)

${ }^{*}$ Corresponding author

\section{To cite this article:}

Ogunnaike Philip Olubunmi, Olatunji Sunday Yinka, Owolabi Joshua Oladele, Olanrewaju Afees John, Baderinwa Deborah Boluwatife, Fabiyi Sunday Oluseyi. Aberrations in Renal Function Parameters Following Oral Administration of Phyllanthus amarus in CadmiumInduced Kidney Damage in Adult Wistar Rats. Journal of Diseases and Medicinal Plants. Vol. 3, No. 4, 2017, pp. 60-67. doi: 10.11648/j.jdmp.20170304.11

Received: September 22, 2017; Accepted: October 4, 2017; Published: October 28, 2017

\begin{abstract}
Renal disease has been found to be the ninth leading cause of death. Environmental pollution is a serious cause for concern nowadays and the exposure of humans to heavy metals released into the environment by several sources produces deleterious and lethal effects. Cadmium (Cd) which is a non-essential heavy metal known to possess toxic effects on living things can be found almost anywhere and its toxicity is of concern to industrial workers and all humans due to its use in some industrial products and also in agriculture. The chief organ of toxic impact in the human is the kidney, where the proximal tubule is a major target of $\mathrm{Cd}$ deposition. The present study investigated if ethanolic extract of Chanca Piedra (CP) (Phyllantus amarus) has any prophylactic or ameliorative effects against nephrotoxicity induced by cadmium sulphate in adult male Wistar rats. A total of forty-two (42) adult male Wistar rats were used for this study and were divided into seven (7) groups (n=6) as follows: Group A (control), Group B (40mg/kg BW), Group C (100mg/kg BW of CP and 40mg/kg BW of Cd), Group D $(200 \mathrm{mg} / \mathrm{kg}$ BW of CP and $40 \mathrm{mg} / \mathrm{kg} \mathrm{BW})$, Group E (40mg/kg BW and $100 \mathrm{mg} / \mathrm{kg}$ BW of CP), Group F (40mg $/ \mathrm{kg}$ BW and $200 \mathrm{mg} / \mathrm{kg}$ BW of CP), Group G (200mg/kg BW of CP). Both cadmium and Chanca Piedra were administered orally through oro-gastric cannula. Results showed that exposure to $\mathrm{Cd}$ lowered the activities of the kidney by increasing the plasma creatinine and urea levels. Exposure to $\mathrm{CP}$ also lowered the activities of the kidney by increasing the plasma creatinine and urea levels. The findings suggest that the administration of $\mathrm{CP}$ extract has no prophylactic or ameliorative effects on cadmium induced kidney damage and continue use of this extracts in the treatment of some diseases may be deleterious to the kidney.
\end{abstract}

Keywords: Nephrotoxicity, Cadmium, Plasma, Creatinine, Urea, Total Protein

\section{Introduction}

Renal disease has been found to be the ninth leading cause of death [1] and renal failure is one of the most common clinical symptoms [2]. Renal failure refers to decline of excretory functions of kidney and it is usually characterized by decrease in glomerular filtration rate (GFR) which results in the abnormal retention of blood urea and serum creatinine which must be excreted [3]. Environmental pollution is a serious cause for concern nowadays and the exposure of humans to heavy metals released into the environment by several sources produces deleterious and lethal effects [4]. The four main groups of environmental pollutants are radio nucleotides, pesticides, petroleum hydrocarbons and heavy metals with heavy metals being the most dangerous source [5]. Cadmium (Cd) is a non-essential heavy metal known to possess toxic effects on living things $[6,7]$. Cadmium can be found almost anywhere and its toxicity is of concern to industrial workers and all humans due to its use in some 
industrial products and also in agriculture [8, 9]. Everyday human activities, such as tobacco smoking, mining, smelting and refining of non-ferrous metals, fossil fuel combustion, incineration of municipal waste (especially cadmiumcontaining batteries and plastics), manufacture of phosphate fertilizers, and recycling of cadmium-plated steel scrap and electric and electronic waste are major ways by which cadmium can be released into the environment [9]. The chief organ of toxic impact in the human is the kidney, where the proximal tubule is a major target of $\mathrm{Cd}$ deposition [10]. About $30 \%$ of body cadmium is deposited in the kidney tubule region [11], therefore a prolonged exposure to cadmium will ultimately lead to renal failure. It is safe to say that cadmium is a confirmed nephrotoxin as it has been confirmed in various experiments to induce oxidative stress $[12,13]$. Chanca piedra is a popular South American herb that has been used traditionally to dissolve and eliminate kidney stones and gallbladder stones. The English translation for Chanca piedra is 'stone crusher'. Scientific studies have provided solid evidence of this therapeutic effect. Chanca piedra extract is well known for its antioxidant properties, this may result from its ability to scavenge free radicals [14]. The present study is aimed at studying the effects of high and low doses of Chanca Piedra on some renal function parameters in cadmium-induced kidney damage in adult Wistar rats.

\section{Materials and Methods}

\subsection{Plant Extract}

The Chanca piedra (CP) leaves were collected from gardens and surroundings of Babcock University, Ilishan Remo, Ogun State in Nigeria. The collected plants were taken to the Botany Department of Obafemi Awolowo University, Ile- Ife, Osun State for identification and later authenticated at the University Herbarium. The plant extraction was carried out at the Department of Pharmacology, Babcock University. The leaves were cleaned, air-dried for 2 weeks after which it was pulverized into dry powder using industrial laboratory grinder. Extraction of the phytochemicals was done by soaking $104 \mathrm{~g}$ of the powder in $500 \mathrm{ml}$ of $50 \%$ ethanol for 72 hours after which the extract was filtered using a white moslin cloth. Crude extract was obtained by filtration followed by concentration of the solvent in an oven at $40^{\circ} \mathrm{C}$ and the evaporation of the plant gave rise to a paste. The paste was weighed and $10 \mathrm{~g}$ of the paste was dissolved in $400 \mathrm{ml}$ of distilled water for the preparation of the stock solution.

\subsection{Nephrotoxic Substance of Use}

The cadmium sulphate was obtained from Sigma Aldrich $\AA$ USA and $5 \mathrm{~g}$ of Cadmium sulphate was dissolved in $200 \mathrm{ml}$ of distilled water and administered daily at a dosage of $40 \mathrm{mg} / \mathrm{kg}$ body weight through oral cannula throughout the period of administration.

\subsection{Animal Care and Treatment}

Forty-two, (42) adult male Wistar rats (Rattus norvegics) between 150-200g were purchased from the disease-free stock of the Babcock University animal house and were left to acclimatize for one week. They were assigned into seven groups on the basis of their weight: A, B, C, D, E, F and G of $(n=6)$ in each group.

The rats were bred with plastic cages with wire screen tops, they were kept under adequate ventilation with room temperature and relative humidity of $29+2^{\circ} \mathrm{C}$ and $40-70 \%$, respectively, with a $12 \mathrm{hr}$ natural light-dark cycle. Pelleted feed and water was given to the animals and good hygiene was maintained by constant cleaning and removal of urine and feces with spilled feed from cages daily.

Table 1. Treatment Protocol

\begin{tabular}{ll}
\hline GROUPS & TREATMENT \\
\hline A & Control: distilled water only \\
B & Cadmium sulphate $(40 \mathrm{mg} / \mathrm{kg}$ body BW) only \\
C & Chanca piedra $(100 \mathrm{mg} / \mathrm{kg} \mathrm{BW})$ and Cadmium sulphate $(40 \mathrm{mg} / \mathrm{kg} \mathrm{BW})$ for the next 14 days $(\mathrm{prophylactic}$ group) \\
D & Chanca Piedra $(200 \mathrm{mg} / \mathrm{kg} \mathrm{BW})$ and Cadmium sulphate $(40 \mathrm{mg} / \mathrm{kg} \mathrm{BW})$ for the next 14 days $(\mathrm{prophylactic}$ group) \\
E & Cadmium sulphate $(40 \mathrm{mg} / \mathrm{kg} \mathrm{BW})$ for 14 days and Chanca Piedra $(100 \mathrm{mg} / \mathrm{kg} \mathrm{BW})$ for the next14 days (ameliorative group) \\
F & Cadmium sulphate $(40 \mathrm{mg} / \mathrm{kg} \mathrm{BW})$ for 14 days and Chanca Piedra $(200 \mathrm{mg} / \mathrm{kg}$ BW) for the next14 days (ameliorative group) \\
G & Chanca Piedra $(200 \mathrm{mg} / \mathrm{kg} \mathrm{BW)} \mathrm{only}$ \\
\hline
\end{tabular}

\subsection{Experimental Etiquette}

The protocol of experimentation was according to the guide to the care and use of animals in research and teachings approved by the Babcock University Research Ethic Committee (BUREC).

\subsection{Measurement of Body Weight, Water Intake and Food Consumption}

The body weight of the animals in grams, was measured daily throughout the period of administration using a weighing balance, this was carried out to observe the weight gain or loss in each group. Also, the food consumption and water intake of the animals in milliliters, were measured daily from the beginning of the experiment through the whole procedure. The volume of water given to each group was measured with a measuring cylinder and the volume of left over water overnight was measured, and the difference between the water volume given and the volume of the leftover water was taken as the daily water intake. Likewise, the food consumption was also measured using a weighing balance and the difference between the previous day quantity and the left-over was taken as the daily food consumption. 


\subsection{Sacrifice and Biochemical Analysis}

At the end of the 28 days administration, the animals were sacrificed through cervical dislocation method and Blood samples were collected through cardiac puncture and later stored in heparinized bottles to obtain plasma. About $5 \mathrm{ml}$ of whole blood was collected and centrifuged at 4000 revolutions for 15 minutes using Gulfex Medical and Scientific Centrifuge, England. The plasma was separated by decantation and analyzed for renal functions test with investigation of total protein, creatinine and urea levels which were determined following strictly the methods described by [15].

\subsection{Statistical Analysis}

Data were expressed as Mean \pm Standard Error of Mean (S.E.M). The statistical significant was evaluated by one way analysis of variance (ANOVA) using Graph Pad Prism5 (Version 5.03, Graph Pad Inc.) followed by Student Newan-Keuls (SNK) test for multiple comparisons. A value of $\mathrm{p}<0.05$ was considered statistically significant.

\section{Results}

\subsection{Body Weight}

Table 2 shows the result of the final body weight of the animals across the groups during the first and the last week of treatment. As shown in the table, the final body weight in the control group A was significantly $(p<0.05)$ higher when compared to the treated groups $\mathrm{C}(\mathrm{LCP}+\mathrm{Cd})$ $(137.8 \pm 5.4), \quad \mathrm{D}(\mathrm{HCP}+\mathrm{Cd})(148.4 \pm 4.5), \mathrm{E}(\mathrm{Cd}$ $+\mathrm{LCP})(142.0 \pm 10.7)$ and $\mathrm{G}(\mathrm{HCP})(123.6 \pm 8.1)$. Group $\mathrm{G}$ (HCP) (123.6 \pm 8.1$)$ body weight was also significantly ( $\mathrm{p}$ $<0.05)$ lower than groups $\mathrm{F}(\mathrm{Cd}+\mathrm{HCP})(163.0 \pm 11.6)$ and $\mathrm{B}(\mathrm{Cd})(161.2 \pm 4.8)$. There was a slight decrease in body weight in group B (Cd) $(161.2 \pm 4.8)$ when compared to the control group A. However, this was not statistically significant $(\mathrm{p}<0.05)$. Also, there was a slight decrease in body weight in group $\mathrm{F}(\mathrm{Cd}+\mathrm{HCP})(163.0 \pm$ 11.6) when compared to the control group A. However, this was also not statistically significant $(\mathrm{p}<0.05)$.

Table 2. Initial and Final Body Weight of the Animals.

\begin{tabular}{llll}
\hline Groups & Initial (average) body weight $(\mathrm{g})$ & Final (average) body weight (g) & Weight loss or weigh gain (g) \\
\hline A $(\mathrm{CONTROL})$ & $125.6 \pm 7.8 \# \delta \beta \AA$ & $181.2 \pm 4.9$ & $55.6 \pm 2.9$ \\
$\mathrm{~B}(\mathrm{Cd})$ & $158.2 \pm 5.8 \#$ & $161.2 \pm 4.8$ & $3.0 \pm 1.0$ \\
$\mathrm{C}(\mathrm{LCP}+\mathrm{Cd})$ & $140.0 \pm 3.4 \# \delta \beta$ & $137.8 \pm 5.4 @$ & $-2.2 \pm 2$ \\
$\mathrm{D}(\mathrm{HCP}+\mathrm{Cd})$ & $167.0 \pm 2.2 \#$ & $148.4 \pm 4.5 @$ & $-18.6 \pm 2.3$ \\
E $(\mathrm{Cd}+\mathrm{LCP})$ & $152.8 \pm 2.4 \#$ & $142.0 \pm 10.7 @$ & $-10.8 \pm 8.3$ \\
F $(\mathrm{Cd}+\mathrm{HCP})$ & $184.4 \pm 7.0$ & $163.0 \pm 11.6$ & $-21.4 \pm 4.6$ \\
G $(\mathrm{HCP})$ & $92.2 \pm 3.8 @ \beta<\delta £ \#$ & $123.6 \pm 8.1 @ \# \beta$ & $31.4 \pm 4.3$ \\
\hline
\end{tabular}

\subsection{Food Intake of Rats in the First Week of Treatment}

\section{INITIAL FEED INTAKE}

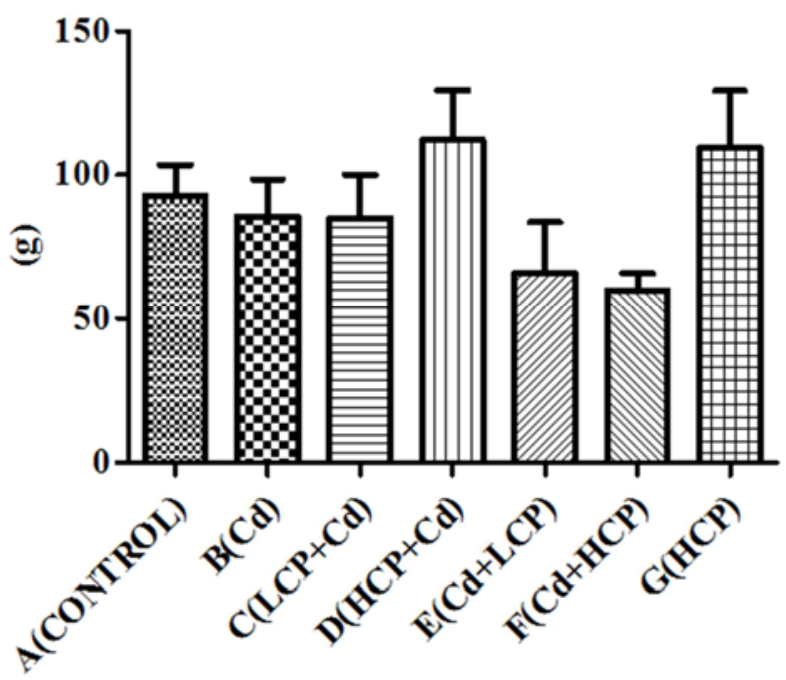

Figure 1. Food Intake of Rats in the First Week of Treatment ( $g$ ). Values are Mean \pm SEM of Data Obtained; $(p<0.05)$. Cadmium $(C d)$, Low dose of Chanca Piedra + Cadmium $(L C P+C d)$, High dose of Chanca Piedra + Cadmium $(\mathrm{HCP}+\mathrm{Cd})$, Cadmium + Low dose of Chanca Piedra $(\mathrm{Cd}+$ LCP), Cadmium + High dose of Chanca Piedra $(\mathrm{Cd}+\mathrm{HCP})$, High dose of Chanca Piedra (HCP).
Figure 1 shows the result of the food intake of the animals during the first week of treatment. As shown in the figure, during the first week of experiment, there was no significant $(p<0.05)$ difference when the food intake of the treated groups were compared with the control group A. There was also no significant $(\mathrm{p}<0.05)$ difference when the food intake of the groups when compared with one another.

\subsection{Food Intake of Rats in the Last Week of Treatment}

Figure 2 shows the result of the food intake of the animals during the last week of treatment. As shown in the figure, during the last week of experiment, there was a significant $(\mathrm{p}<0.05)$ decrease in food intake when groups $\mathrm{B}(\mathrm{Cd})(112.6 \pm 4.64), \mathrm{C}(\mathrm{LCP}+\mathrm{Cd})(49.29 \pm 6.24), \mathrm{D}$ $(\mathrm{HCP}+\mathrm{Cd})(47.43 \pm 3.10), \mathrm{E}(\mathrm{Cd}+\mathrm{LCP})(63.57 \pm 9.22), \mathrm{F}$ $(\mathrm{Cd}+\mathrm{HCP})(79.29 \pm 6.73), \mathrm{G}(\mathrm{HCP})(73.43 \pm 7.76)$ when compared with the control group A $(112.6 \pm 4.64)$. The food intake in groups $\mathrm{C}(\mathrm{LCP}+\mathrm{Cd})(49.29 \pm 6.24), \mathrm{D}(\mathrm{HCP}+\mathrm{Cd})$ $(47.43 \pm 3.10)$ were also significantly $(\mathrm{p}<0.05)$ lower than $\mathrm{B}$ (Cd) $(75.14 \pm 7.73)$. The food intake in groups $\mathrm{C}(\mathrm{LCP}+\mathrm{Cd})$ $(49.29 \pm 6.24), \mathrm{D}(\mathrm{HCP}+\mathrm{Cd})(47.43 \pm 3.10)$ were also significantly $(\mathrm{p}<0.05)$ lower when compared to group $\mathrm{B}$ (Cd) $(75.14 \pm 7.73)$. The food intake in groups $\mathrm{C}(\mathrm{LCP}+\mathrm{Cd})$ $(49.29 \pm 6.24), \mathrm{D}(\mathrm{HCP}+\mathrm{Cd})(47.43 \pm 3.10)$ were significantly $(\mathrm{p}<0.05)$ lower when compared to group $G$ 
(HCP) $(73.43 \pm 7.76)$.

FINAL FEED INTAKE

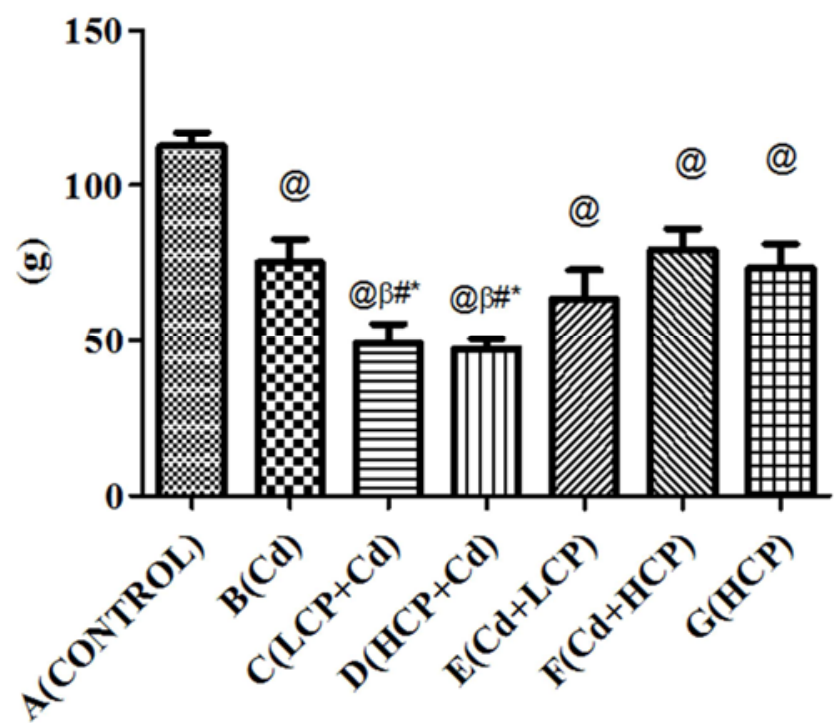

Figure 2. Food Intake of Rats in the Last Week of Treatment (g). Values are Mean \pm SEM of Data Obtained; @ = Significantly Different from A (control); $\beta=$ Significantly Different from B(Cd); \# = Significantly Different from $F(C d+H C P) ; *$ Significantly Different from $G(H C P)$ : $(p<0.05)$. Cadmium $(C d)$, Low dose of Chanca Piedra + Cadmium $(L C P+C d)$, High dose of Chanca Piedra + Cadmium $(H C P+C d)$, Cadmium + Low dose of Chanca Piedra $(C d+L C P)$, Cadmium + High dose of Chanca Piedra $(C d+$ $H C P)$, High dose of Chanca Piedra (HCP).

\subsection{Water Intake of Rats in the First Week of Treatment}

\section{INITIAL WATER INTAKE}

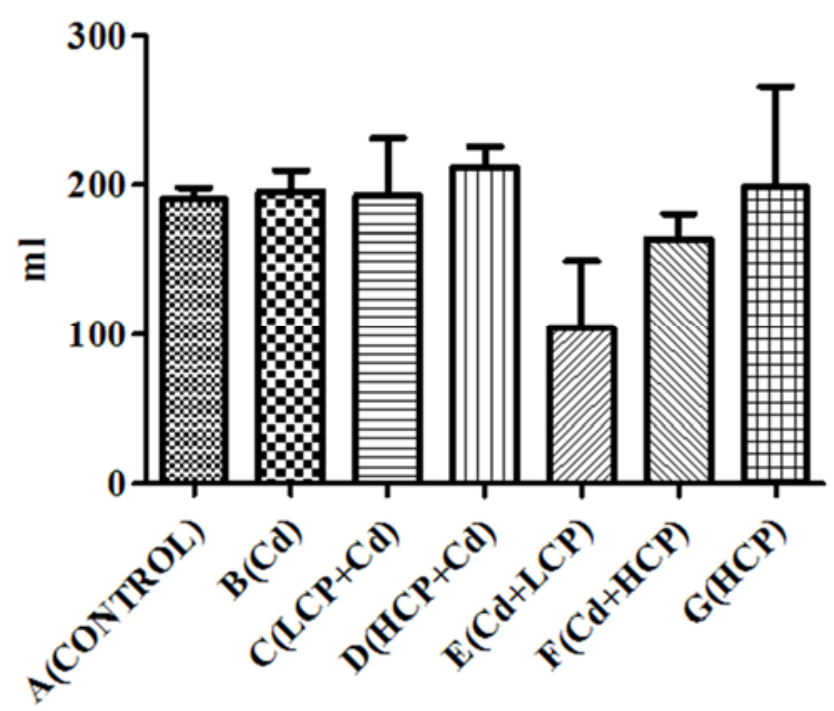

Figure 3. Water Intake of Rats in the First Week of Treatment $(\mathrm{ml})$. Values are Mean \pm SEM of Data Obtained; $(p<0.05)$. Cadmium $(C d)$, Low dose of Chanca Piedra + Cadmium $(L C P+C d)$, High dose of Chanca Piedra + Cadmium $(\mathrm{HCP}+\mathrm{Cd})$, Cadmium + Low dose of Chanca Piedra $(\mathrm{Cd}+$ $L C P)$, Cadmium + High dose of Chanca Piedra $(\mathrm{Cd}+\mathrm{HCP})$, High dose of Chanca Piedra (HCP).

Figure 3 shows the result of the water intake of the rats in the first week of treatment. No significant difference in water intake was observed when the experimental groups were compared to the control group A. There was also no significant $(\mathrm{P}<0.05)$ difference in water intake when the experimental groups were compared among themselves. There was a noticeable reduction in water intake when group $\mathrm{E}(\mathrm{Cd}+\mathrm{LCP})$ $(104.3 \pm 45.2)$ was compared to the control group and the other groups. However, this was not significant $(\mathrm{P}<0.05)$ statistically.

\subsection{Water Intake of Rats in the Last Week of Treatment}

\section{FINAL WATER INTAKE}

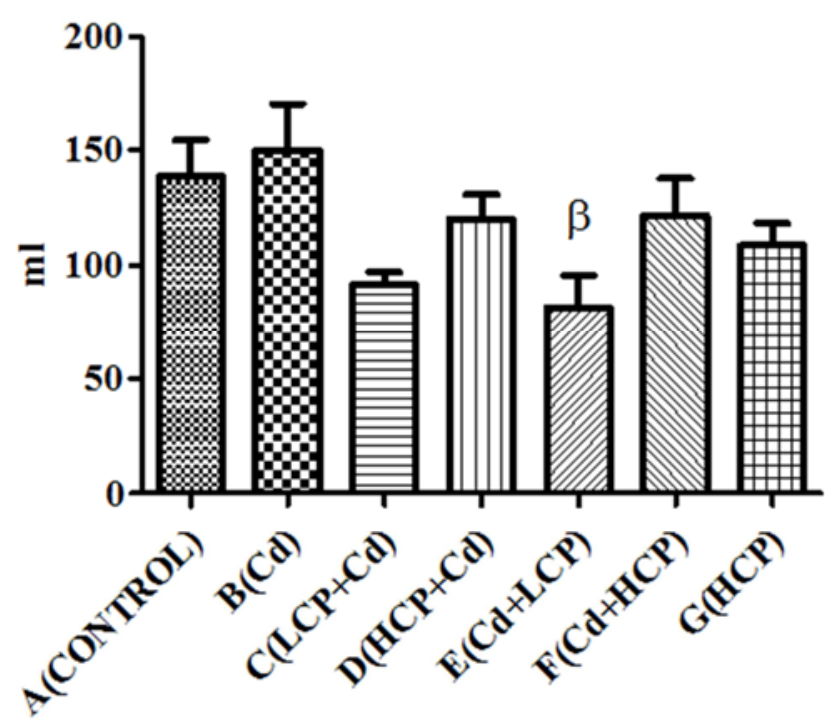

Figure 4. Water Intake of Rats in the Last Week of Treatment $(\mathrm{ml})$. Values are Mean \pm SEM of Data Obtained; $\beta=$ Significantly Different from $B(C d):(p<$ 0.05). Cadmium (Cd), Low dose of Chanca Piedra + Cadmium $(L C P+C d)$, High dose of Chanca Piedra + Cadmium $(H C P+C d)$, Cadmium + Low dose of Chanca Piedra $(\mathrm{Cd}+\mathrm{LCP})$, Cadmium +High dose of Chanca Piedra $(\mathrm{Cd}+\mathrm{HCP})$, High dose of Chanca Piedra $(\mathrm{HCP})$.

Figure 4 shows the result of the water intake of the rats in the last week of treatment. No significant difference in water intake was observed when the experimental groups were compared to the control group A. However, the water intake of group E $(\mathrm{Cd}+$ LCP) $(81.4 \pm 14.1)$ was significantly $(\mathrm{p}<0.05)$ lower than group $\mathrm{B}$ (Cd) $(150.0 \pm 20.6)$.

\subsection{Plasma Creatinine Level in the Control and Treated Groups}

Figure 5 shows the result of the plasma creatinine level across the groups. As shown in figure 5, the plasma creatinine level of groups $\mathrm{B}(\mathrm{Cd})(0.1230 \pm 0.0016), \mathrm{C}(\mathrm{LCP}+\mathrm{Cd})(0.1194 \pm$ $0.0012), \mathrm{D}(\mathrm{HCP}+\mathrm{Cd})(0.1216 \pm 0.0023), \mathrm{E}(\mathrm{Cd}+\mathrm{LCP})$ $(0.1276 \pm 0.0015), \mathrm{F}(\mathrm{Cd}+\mathrm{HCP})(0.1236 \pm 0.0014), \mathrm{G}(\mathrm{HCP})$ $(0.1334 \pm 0.0014)$ were significantly $(\mathrm{p}<0.05)$ higher when compared to the control group A $(0.0326 \pm 0.0194)$. However, there was no significant $(\mathrm{P}<0.05)$ difference among the treated groups when compared with one another. 


\section{PLASMA CREATININE}

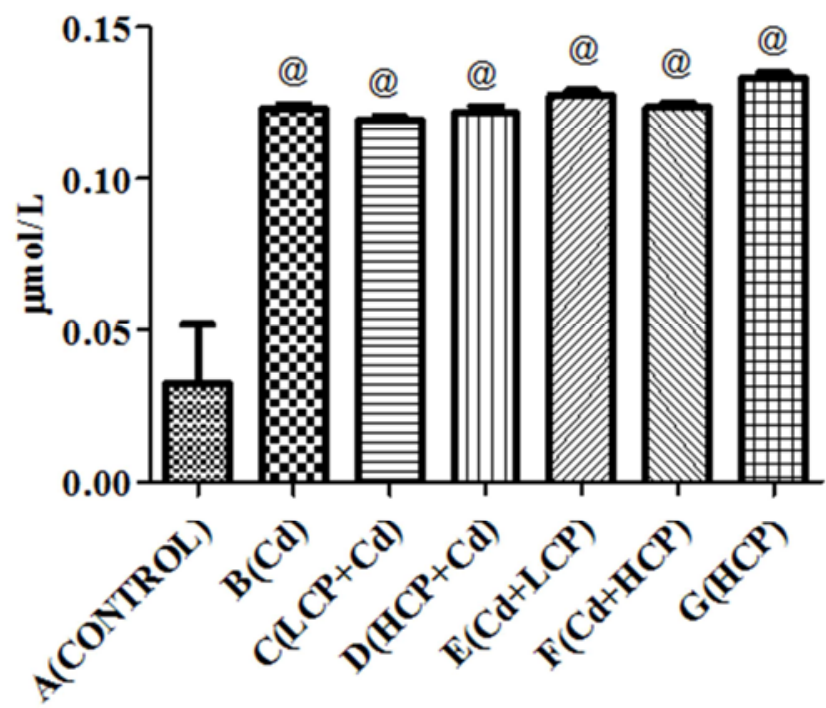

Figure 5. Plasma Creatinine Level $(\mu \mathrm{mol} / \mathrm{L})$. Values are Mean $\pm S E M$ of Data Obtained; @=Significantly Different from A (Control): $(p<0.05)$. Cadmium (Cd), Low dose of Chanca Piedra + Cadmium $(L C P+C d)$, High dose of Chanca Piedra + Cadmium $(H C P+C d)$, Cadmium + Low dose of Chanca Piedra $(C d+L C P)$, Cadmium + High dose of Chanca Piedra $(C d+$ $\mathrm{HCP})$, High dose of Chanca Piedra (HCP).

\subsection{Plasma Urea Levels in Control and Treated Groups}

\section{PLASMA UREA}

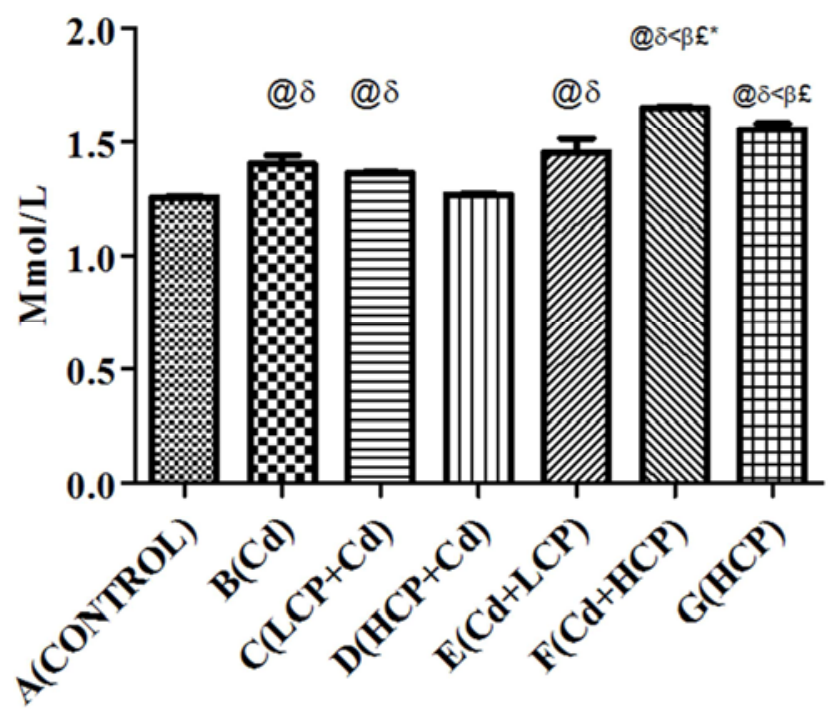

Figure 6. Plasma Urea Level (Mmol/L) Values are Mean \pm SEM of Data Obtained; @ = Significantly Different from A (Control); $\beta=$ Significantly Different from $B(C d) ;<=$ Significantly Different from $C(L C P+C d) ; \delta=$ Significantly Different from $\mathrm{D}(\mathrm{HCP}+\mathrm{Cd}) ; £=$ Significantly Different from $E(C d+L C P) *=$ Significantly Different from $G(H C P):(p<0.05)$. Cadmium (Cd), Low dose of Chanca Piedra + Cadmium $(L C P+C d)$, High dose of Chanca Piedra + Cadmium $(\mathrm{HCP}+\mathrm{Cd})$, Cadmium + Low dose of Chanca Piedra $(\mathrm{Cd}+\mathrm{LCP})$, Cadmium + High dose of Chanca Piedra $(\mathrm{Cd}+$ HCP), High dose of Chanca Piedra (HCP).

Figure 6 shows the result of the plasma urea levels across the groups. As shown in figure 6, the plasma urea level of groups $\mathrm{B}$ (Cd) $(1.403 \pm 0.037), \mathrm{C}(\mathrm{LCP}+\mathrm{Cd})(1.361 \pm 0.004), \mathrm{E}(\mathrm{Cd}+$
LCP) $(1.453 \pm 0.061), \mathrm{F}(\mathrm{Cd}+\mathrm{HCP})(1.651 \pm 0.003), \mathrm{G}(\mathrm{HCP})$ $(1.556 \pm 0.025)$ were significantly $(\mathrm{p}<0.05)$ higher than group A $(1.255 \pm .0 .006)$. There was also a significant $(\mathrm{p}<0.05)$ increase in the plasma urea level of groups $\mathrm{F}(\mathrm{Cd}+\mathrm{HCP})(1.651$ $\pm 0.003)$ and $\mathrm{G}(\mathrm{HCP})(1.556 \pm 0.025)$ when compared to group $\mathrm{B}(\mathrm{Cd})(1.403 \pm 0.037)$. The plasma Urea level of groups $\mathrm{F}(\mathrm{Cd}+\mathrm{HCP})(1.651 \pm 0.003)$ and $\mathrm{G}(\mathrm{HCP})(1.556$ $\pm 0.025)$ were significantly $(\mathrm{P}<0.05)$ higher when compared to group C $(\mathrm{LCP}+\mathrm{Cd})(1.361 \pm 0.004)$. Groups $\mathrm{B}(\mathrm{Cd})(1.403 \pm 0.037), \mathrm{C}(\mathrm{LCP}+\mathrm{Cd})(1.361 \pm 0.004), \mathrm{E}$ $(\mathrm{Cd}+\mathrm{LCP})(1.453 \pm 0.061), \mathrm{F}(\mathrm{Cd}+\mathrm{HCP})(1.651 \pm$ $0.003), \mathrm{G}(\mathrm{HCP})(1.556 \pm 0.025)$ were also significantly ( $\mathrm{p}$ $<0.05)$ higher when compared to group $\mathrm{D}(1.267 \pm$ $0.004)$. The plasma urea level of $\mathrm{F}(\mathrm{Cd}+\mathrm{HCP})(1.651 \pm$ $0.003)$ and $\mathrm{G}(\mathrm{HCP})(1.556 \pm 0.025)$ were significantly $(\mathrm{p}$ $<0.05)$ higher than group E $(\mathrm{Cd}+\mathrm{LCP})(1.453 \pm 0.061)$. Group F $(\mathrm{Cd}+\mathrm{HCP})(1.651 \pm 0.003)$ plasma urea level was significantly $(\mathrm{p}<0.05)$ higher than Group G (HCP) $(1.556 \pm 0.025)$.

\subsection{Plasma Total Protein Level in Control and Treated Groups}

\section{PLASMA TOTAL PROTEIN}

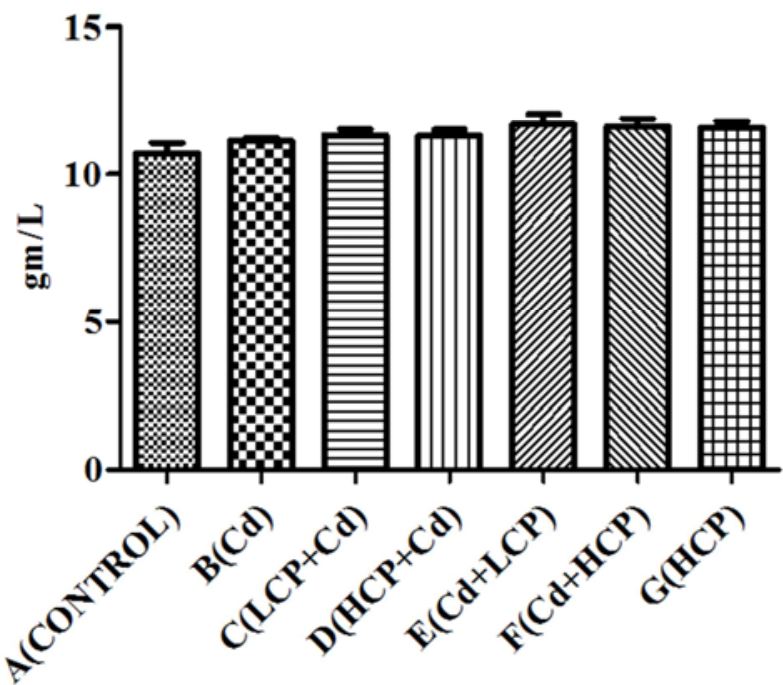

Figure 7. Plasma Total Protein Level $(\mathrm{gm} / \mathrm{L})$ Values are Mean \pm SEM of Data Obtained: $(p<0.05)$. Cadmium $(C d)$, Low dose of Chanca Piedra + Cadmium $(\mathrm{LCP}+\mathrm{Cd})$, High dose of Chanca Piedra + Cadmium $(\mathrm{HCP}+$ $C d)$, Cadmium + Low dose of Chanca Piedra $(C d+L C P)$, Cadmium + High dose of Chanca Piedra $(\mathrm{Cd}+\mathrm{HCP})$, High dose of Chanca Piedra (HCP).

Figure 7 shows the result of the plasma protein level of the animals. There was no statistical significance when the plasma total protein of the experimental groups were compared with the control group. There was also no significant difference when the experimental groups were compared with one other.

Values are mean \pm SEM of data obtained; @ = significantly different from A (control); $\beta=$ significantly different from $\mathrm{B}(\mathrm{Cd}) ;<=$ significantly different from $\mathrm{C}(\mathrm{LCP}+\mathrm{Cd}) ; \delta=$ significantly different from $\mathrm{D}(\mathrm{HCP}+$ $\mathrm{Cd}) ; £=$ significantly different from $\mathrm{E}(\mathrm{Cd}+\mathrm{LCP}) *=$ 
significantly different from G(HCP): $(p<0.05)$. Cadmium $(\mathrm{Cd})$, Low dose of Chanca piedra + Cadmium $(\mathrm{LCP}+\mathrm{Cd})$, High dose of Chanca piedra + Cadmium $(\mathrm{HCP}+\mathrm{Cd})$, Cadmium + Low dose of Chanca piedra $(\mathrm{Cd}+\mathrm{LCP})$, Cadmium + High dose of Chanca piedra $(\mathrm{Cd}+\mathrm{HCP})$, High dose of Chanca piedra (HCP).

\section{Discussion}

In this present study, the body weight of the animals in the control group (A) was significantly $(\mathrm{p}<0.05)$ higher than the cadmium treated group $\mathrm{B}$ and the rest of the chanca piedra and cadmium treated groups $\mathrm{C}(100 \mathrm{mg} / \mathrm{kg} \mathrm{BW} \mathrm{CP}+$ $40 \mathrm{mg} / \mathrm{kg} \mathrm{BW} \mathrm{Cd}), \mathrm{D}(200 \mathrm{mg} / \mathrm{kg} \mathrm{BW} \mathrm{CP}+40 \mathrm{mg} / \mathrm{kg} \mathrm{BW} \mathrm{Cd})$, $\mathrm{E},(40 \mathrm{mg} / \mathrm{kg} \mathrm{BW} \mathrm{Cd}+100 \mathrm{mg} / \mathrm{kg} \mathrm{CP})$ and $\mathrm{F}(40 \mathrm{mg} / \mathrm{kg} \mathrm{BW}$ $\mathrm{Cd}+200 \mathrm{mg} / \mathrm{kg} \mathrm{BW} \mathrm{CP})$. There was also a significant $(\mathrm{p}<$ 0.05 ) decrease in body weight in the chanca piedra treated group when compared to the control group. There was also significant $(p<0.05)$ decrease when the body weight in the chanca piedra treated group was compared with the control group. The loss in body weight in the experimental groups were accompanied with decrease in food intake in the treated groups. This may have resulted from loss of appetite caused by cadmium [16] and it can also be attributed to depression of the feeding centre located in the hypothalamus [17]. However, this needs to be further investigated. There was no significant difference in the water when the control group was compared to the cadmium treated group, this is in contrast with Ogunnaike et al [18] who reported that cadmium intake caused decrease in water intake which could be attributed to the depression of thirst centre located in the lateral hypothalamus [17]. There was also no significant difference in water intake when the other treated groups $\mathrm{C}$ (100mg/kg BW CP + 40mg/kg BW Cd), D (200mg/kg BW $\mathrm{CP}+40 \mathrm{mg} / \mathrm{kg} \mathrm{BW} \mathrm{Cd}), \mathrm{E}(40 \mathrm{mg} / \mathrm{kg} \mathrm{BW} \mathrm{Cd}+100 \mathrm{mg} / \mathrm{kg}$ $\mathrm{BW} \mathrm{CP})$ and $\mathrm{F}(40 \mathrm{mg} / \mathrm{kg} \mathrm{BW} \mathrm{Cd}+200 \mathrm{mg} / \mathrm{kg} \mathrm{BW} \mathrm{CP})$ were compared to the control. Also, there was no significant ( $\mathrm{p}<$ 0.05 ) difference when the chanca piedra treated group was compared the control group. However, little or no research has been done on the effects of Chanca piedra on appetite or thirst. Hence, these areas need to be further investigated.

Various substances excreted and reabsorbed by the kidney can prove useful in studying kidney function. Some of them include: Creatinine, Urea, Total protein. Creatinine is a breakdown product of creatinine phosphate in the muscle, and is usually produced at a fairly constant rate by the body (depending on muscle mass). It is one of the substances normally eliminated from the body by the kidneys through glomerular filtration and proximal tubule secretion. Serum creatinine is an important indicator of renal health because it is an easily measured by the kidneys. If filtration in the kidney is deficient, creatinine blood level rises, therefore, creatinine levels in blood can be used to measure creatinine clearance, which correlates with glomerular filtration rate. The plasma urea nitrogen test is a measure of the amount of nitrogen in the blood that comes from urea. It is used as a marker of renal function [19].
In this study, animals treated with cadmium resulted in distortion in kidney function, evidenced by increased plasma creatinine and urea when compared to the control group. This may be attributed to alterations in Glomerular filtration rate leading to reduction in the amount of creatinine and urea which was filtered out of the blood. These findings correlate with earlier report [18] that cadmium affected Glomerular filtration rate and this led to the retention of urea and creatinine in the blood. Also, the significantly $(p<0.05)$ elevated level of creatinine in the cadmium treated groups when compared to the control group A could be attributed to oxidative damage to the kidney by cadmium, in agreement with the works of Renugadevi and Prabu, where cadmium administration led to an elevated level of creatinine [20, 21]. This was also linked to the defect in glomerular filtration rate. Shatti [22] reported that the rise in creatinine level is an indication of renal tubular damage due to Cadmium induced nephrotoxicity [22]. The increase in plasma creatinine concentration is an evidence of reduced ability of the renal tubules to extract and remove creatinine from the plasma of the cadmium treated group, which can be due to the occlusion of in the lumen of the Proximal Convoluted tubule. Creatinine is the most trustable renal function marker and increase only when majority of renal function is lost [23].

The significant $(\mathrm{p}<0.05)$ increase in plasma urea concentration in the cadmium treated group is an evidence of the reduced ability of the renal tubules to extract and remove urea from the plasma of the cadmium treated group, a fact supported by Girolami et al., [24]. The changes in creatinine and urea level in this experiment concluded the severe injurious effects of cadmium to the kidney.

The chanca piedra treated group also had increase in plasma urea and creatinine level when compared to the controlled group. Also, the cadmium and chanca piedra treated groups C $(100 \mathrm{mg} / \mathrm{kg} \mathrm{BW} \mathrm{CP}+40 \mathrm{mg} / \mathrm{kg} \mathrm{BW} \mathrm{Cd}), \mathrm{D}$ $(200 \mathrm{mg} / \mathrm{kg} \mathrm{BW} \mathrm{CP}+40 \mathrm{mg} / \mathrm{kg} \mathrm{BW} \mathrm{Cd}), \mathrm{E}(40 \mathrm{mg} / \mathrm{kg} \mathrm{BW} \mathrm{Cd}$ $+100 \mathrm{mg} / \mathrm{kg} \mathrm{BW} \mathrm{CP})$ and $\mathrm{F}(40 \mathrm{mg} / \mathrm{kg} \mathrm{BW} \mathrm{Cd}+200 \mathrm{mg} / \mathrm{kg}$ BW CP) also had a significant $(\mathrm{p}<0.05)$ increase in creatinine and urea concentration when compared to the control group. The results in groups C $(100 \mathrm{mg} / \mathrm{kg} \mathrm{BW} \mathrm{CP}+$ $40 \mathrm{mg} / \mathrm{kg} \mathrm{BW} \mathrm{Cd}), \mathrm{D}(200 \mathrm{mg} / \mathrm{kg} \mathrm{BW} \mathrm{CP}+40 \mathrm{mg} / \mathrm{kg} \mathrm{BW}$ $\mathrm{Cd}), \mathrm{E}(40 \mathrm{mg} / \mathrm{kg} \mathrm{BW} \mathrm{Cd}+100 \mathrm{mg} / \mathrm{kg} \mathrm{BW} \mathrm{CP})$ and $\mathrm{F}$ $(40 \mathrm{mg} / \mathrm{kg} \mathrm{BW} \mathrm{Cd}+200 \mathrm{mg} / \mathrm{kg} \mathrm{BW} \mathrm{CP})$ gives an indication that Chanca Piedra at the dosages used in this research does not have any ameliorative or prophylactic effects on cadmium induced kidney damage revealed by plasma creatinine and urea concentration. However, this needs to be further investigated.

There was no significant $(\mathrm{p}<0.05)$ difference when the plasma total proteins of the cadmium treated group was compared to the Control group. This is in contrast with [25] who reported that cadmium decreases serum total protein due to disorder in protein synthesis, metabolism and necrosis as a result of individual actions or interactions of the complex constituents of the metals. However, this needs to be further investigated. There was also no significant difference when the plasma total proteins of the chanca piedra treated group 
was compared to the control group. This needs to be further investigated because little or no work has been done to study the effects of chanca piedra on plasma total protein. Also, no significant difference was observed in the plasma total protein levels when the cadmium and chanca piedra treated groups C $(100 \mathrm{mg} / \mathrm{kg} \mathrm{BW} \mathrm{CP}+40 \mathrm{mg} / \mathrm{kg} \mathrm{BW} \mathrm{Cd})$, D (200mg/kg BW CP + 40mg/kg BW Cd), E (40mg/kg BW Cd $+100 \mathrm{mg} / \mathrm{kg} \mathrm{BW} \mathrm{CP})$ and $\mathrm{F}(40 \mathrm{mg} / \mathrm{kg} \mathrm{BW} \mathrm{Cd}+200 \mathrm{mg} / \mathrm{kg}$ $\mathrm{BW} \mathrm{CP})$ were compared to the control group. It is recommended that this is further investigated.

\section{Conclusion}

In conclusion, it was observed that cadmium induced a significant elevation in the plasma creatinine and urea levels but it had no influence in the total protein level. It was also observed that Chanca piedra also increased plasma creatinine and urea levels but had no influence on the total protein level of the treated group. However, it was demonstrated that Chanca piedra both at high and low doses administered daily for 14 days had no prophylactic or ameliorative effects on renal damage, this however remains controversial, hence further investigation is required. Further investigation on the isolation and identification of the active components responsible for these effects should be carried out. However, it can be said that Chanca piedra has no ameliorative or prophylactic effects on cadmium-induced kidney damage and continue use of this extracts in the treatment of some diseases may be deleterious to the kidney.

\section{References}

[1] Priyadarshini, Abhishek Negi, Shahrukh Husain (2017). A Review on Role of miRNA in Kidney Diseases. Journal of Global Pharma Technology; 05(9):28-36.

[2] Alexander M, Bradbury BD, Kewalramani R, Barlev A, Mohanty SA, Globe D. (2009) Chronic kidney disease and US healthcare resource utilization in a nationally representative sample. Am J Nephrol; 29(5):473-482.

[3] Sembulingam K, Prema S. 2012. Essentials of Medical Physiology (6th edn). Jaypee Brothers Medical Publishers.

[4] Arisawa K, Uemera H, Hiyoshi M, Dakeshita, Kitayama A, Saito H. (2007). cause specific mortality and cancer incidence rates in relation to urinary beta2-microglobulin: 23-year follow-up study in a cadmium-polluted area. toxicology letter, $28,168-174$.

[5] Shaima Meryem (2014) Health Risk Assessment and Oxidative Stress in Workers Exposed to Welding Fumes. Toxicological and Environmental Chemistry 97.

[6] Long C, Juan Z, Wei G, Ying-Zi J (2003) Action of NO and TNF- $\alpha$ release of rats with cadmium loading in malfunction of multiple system organs. Acta Physiologica Sinica 55 (5): 535540 .

[7] Kaplan M, Atakan I. H, Aydigdu N, (2008) Influence of Nacetylcysteine on renal toxicity of cadmium in rats. Pediatr Nephrol 23: 233-241.
[8] Othman Z. A, Hashem A, Habila M. A (2011) Kinetic, equilibrium and thermodynamic studies of cadmium (II) absorption by modified agricultural wastes. Molecules 15: 10443-10456.

[9] Patra R. C, Rautray A. K, and Swarup D. (2011). oxidative stress in lead and cadmium toxicity and its amelioration. Veterinary Medicine International.

[10] Akesson A, Lundh T, Vahter M, et al., (2005). Tubular and glomerular kidney effects in Swedish women with low environmental cadmium exposure. Environmental Health Perspectives, 113(4), 1627-1631.

[11] Nordberg M. and Nordberg G. F (2002). "Chapter 8", in Heavy Metals in the Environment, B. Sarkar, Ed pp.231-270, Marcel Dekker, New York, USA.

[12] Liu J, Qian S. Y, Guo Q, Jiang J, Waalkes M. P, Mason R. P, Kadiiska M. B. (2008). Cadmium generates reactive oxygen and carbon-centered radical species in rats: insights from in vivo spin-trapping studies. Free Radical Biol Med 45: 475481.

[13] Chen L, Liu L, Huang S. (2008). Cadmium activates the mitogen-activated protein-kinase (MAPK) pathay via induction of reactive oxygen species and inhibition of protein phosphatises 2A and 5. Free Radical Biol Med 45: pp. 10351044.

[14] Naaz, F., Javed, S., Abdin, M. Z. (2007). Hepatoprotective effect of ethanolic extract of Phyllanthus amarus Schum. et Thonn. on. J Ethnopharmacol, 113, 503-509.

[15] Ranjna Chawla (1999) Practical Clinical Biochemistry; Methods and Interpretations, second edition. Jaypee Brothers Medical Publishers (P) Ltd. ISBN 81-7179-637-0.

[16] Hounkpatin A. S, Edorh P. A, Guedenon P, Alimba C. G, Ogunkanmi A, Dougnon T, Boni G, Aissi K, Montcho S, Loko F, Ouazzani N, Mandi L, Boko M, Creppy E (2013) Haematological evaluation of Wistar rats exposed to chronic doses of cadmium, mercury and combined cadmium and mercury. Academic Journals. Vol 12 (23): 3731-3737.

[17] Guyton A., Hall J. E. (2000). Textbook of medical physiology (10th ed., pp. 369-371, 373-378). Philadelphia: W. B. Saunders.

[18] Ogunnaike Philip Olubunmi, Olatunji Sunday Yinka, Owolabi Joshua Oladele, Fabiyi Adetutu Olubusayo, Olanrewaju John Afees. An Assessment of Renal Function Parameters on the Ameliorative Properties of Ginkgo Biloba Extract in Cadmium-Induced Nephrotoxicity in Adult Wistar Rats Model. American Journal of Clinical and Experimental Medicine. Vol.

[19] Jasdeep Kaur, Benjamin E. Young and Paul J. Fadel (2017). Sympathetic Overactivity in Chronic Kidney Disease: Consequences and Mechanisms Int. J. Mol. Sci. 2017, 18 (218).

[20] Renugadevi J, Lamas M, Martin D, Islas S, Luna J (2012) Naringenin protects against cadmium-induced oxidative renal dysfunction in rats. Toxicol 256: 128-134.

[21] Shagirtha K, Muthumani M, Prabu S. M. (2011). Melatonin abrogates cadmium induced oxidative stress related neurotoxicity in rats. European Review for medical and pharmacological sciences, 15(9), 1039-1050. 
[22] Shatti A. A (2011) Effects of Origanum majorana L. On cadmium induced hepatotoxicity and nephrotoxicity in albino rats. 32 (8): 15-20.

[23] Borges LP, Borges VC, Moro AV, Nogueira CW, Rocha JB, Zeni G (2005). Protective effect of diphenyl diselenide on acute liver damage induced by 2-nitropropane in rats. Toxicology. 210:1-8.
[24] Girolami J. P, Cabos G, Manuel Y (1989). Renal kallikrin excretion as a distal nephrotoxicity marker during cadmium exposure in rat. J Toxicol 55: pp. 117-126.

[25] Olivier B, Gregory J, Michel T, Marc C (2005) Effect of heavy metals on, and handling by, the kidney. Nephron Physiol. 99: 105-110. 